\begin{tabular}{|l|l|l|l|l|l|}
\hline J. Tek. Ling & Vol.11 & No.2 & Hal. 139 - 145 & Jakarta, Mei 2010 & ISSN 1441-318X \\
\hline
\end{tabular}

\title{
APLIKASI GA3 DALAM MEMECAHKAN DORMANSI BIJI Picrasma javanica SETELAH PENYIMPANAN PADA BERBAGAI SUHU SIMPAN
}

\author{
Ning Wikan Utami \\ Peneliti di Bidang Botani, Pusat Penelitian Biologi-LIPI \\ Email: wikan.utami@yahoo.com
}

\begin{abstract}
Picrasma javanica is one of the medicinal plants that has an anti malaria potency, it is belonging into Simaroebaceae family. The aim of this research is to know the effect of GA3 on broken dormancy of P. Javanica seed after storaged in the various temperature to enhance and increased seed germination. The experiment was carried out in the Macropropagation Laboratory, Cibinong Science Center, Research Center for Biology, LIPI, using a Complete Randomized Design with two factors in three replication. The first factor is condition of storage i.e room $\left(28 \pm 1^{\circ} \mathrm{C}, \mathrm{RH} 80 \%\right)$, incubator $\left(20^{\circ} \mathrm{C}\right.$, $\mathrm{RH} 90 \%)$, incubator ( $\left.5^{\circ} \mathrm{C}, \mathrm{RH} 95 \%\right)$ dan deep freezer $\left(-20^{\circ} \mathrm{C}, \mathrm{RH}\right)$. The second factor is long of storage i.e. 1,2,3,4,5 and 5 months. GA3 100 ppm was used for broken seed dormancy. The result showed that there was no interaction between temperature and long of storage. GA3 solution can be broken on seed dormancy before and after storage in the various temperature excepted in deep freezer $\left(-20^{\circ} \mathrm{C}, \mathrm{RH} 65 \%\right)$, there are no seed germinate since 1 month storage. P. javanica seed that storage in incubator $5^{\circ} \mathrm{C}$ is the best method and after 5 months the germination percentage is still high $(73,3 \%)$ with GA3 but only 18,33\% without GA3. On the other treatments the germination percentage is less than $50 \%$. The highest germination value $(14,1)$ that was recorded in the seeds that storage in incubator $\left(20^{\circ} \mathrm{C}, \mathrm{RH} .95 \%\right)$.
\end{abstract}

Key words: GA3, dormancy, temperature, long of storage, seed, P. javanica

\section{PENDAHULUAN}

\subsection{Latar Belakang}

Salah satu famili tumbuhan obat yang berpotensi untuk pengobatan penyakit penting di daerah tropika (malaria) adalah Simaroebaceae. Famili ini meliputi 300 genus, yang mencakup sekitar 200 species, terdistribusi di Amerika tropis sebagai pusat sebaran utama dan di Afrika Barat sebagai pusat sebaran kedua. Picrasma javanica adalah salah satu jenis yang termasuk dalam famili Simaroebaceae yang telah dimanfaatkan obat secara turun temurun oleh masyarakat di daerah Sumatera dan keberadaannya dilaporkan terancam punah. ${ }^{1,2)}$. Pemanfaatan tumbuhan sebagai bahan obat alami telah digunakan oleh hampir semua kalangan, bahkan telah diproduksi dalam skala industri rumah maupun industri besar sebagai komoditi ekspor. Eksploitasi tumbuhan obat yang tidak terkendali dan perubahan fungsi lahan tanpa memperhatikan pelestariannya mengakibatkan populasinya menurun drastis. Banyak tumbuhan obat yang menghilang pada angka yang mengkhawatirkan. ${ }^{15)}$ Komponen kimia pada ekstrak kulit batang 
ki pahit adalah alkaloid, flavonoid, saponin, tannin, dan steroid/ triterpenoid dan hasil uji laboratorium menunjukkan bahwa $P$. javanica terbukti mempunyai kandungan senyawa aktif sebagai antimalaria. ${ }^{12)} \cdot P$. javanica yang menghasilkan kulit kayu berkhasiat obat malaria seperti kina ${ }^{10)}$, menghasilkan biji yang masih rendah daya perkecambahannya (10-15\% pada suhu 30$32^{\circ} \mathrm{C}$ ). Perkecambahan biji dipengaruhi oleh faktor luar/lingkungan (suhu, kelembaban, cahaya) dan faktor dalam (dormansi kulit biji, embrio). Untuk mempertahankan viabilitas biji tetap tinggi diperlukan suhu simpan yang sesuai. Setelah mengalami penyimpanan, biji tidak mau berkecambah atau memerlukan waktu yang lama untuk berkecambah bisa disebabkan oleh beberapa factor antara lain biji mengalami kerusakan atau dalam keadaan dorman dan juga kondisi simpan (suhu dan kelembaban) yang tidak sesuai. Dormansi biji dapat disebabkan beberapa faktor antara lain kulit biji yang keras, embrio yang dorman dan adanya zat penghambat. Untuk mempercepat dan meningkatkan perkecambahan biji dilakukan berbagai cara untuk memecahkan dormansi biji antara lain dengan hormon tumbuh. GA3 merupakan salah satu hormon yang sering digunakan untuk memacu perkecambahan biji ${ }^{3,10)}$

\subsection{Tujuan Penelitian}

Penelitian dilakukan untuk mengetahui pengaruh GA3 dalam memecahkan dormansi biji $P$. javanica setelah penyimpanan pada berbagai suhu guna memperoleh perkecambahan yang cepat dan tetap tinggi. Dari hasil penelitian ini diharapkan dapat diperoleh cara memecahkan dormansi biji $P$ javanica untuk mempercepat dan meningkatkan perkecambahan serta suhu penyimpanan yang tepat untuk mempertahankan viabilitas tetap tinggi setelah penyimpanan

\section{METODOLOGI}

Penelitian dilakukan di Laboratorium
Fisiologi Makropropagasi dan Konservasi, Cibinong Science Center mulai bulan Maret sampai Sepetember 2008. Bahan penelitian yang digunakan adalah buah $P$. javanica yang masak fisiologis, diperoleh dari Kebun Raya Bogor. Percobaan menggunakan Rancangan Acak Lengkap yang disusun faktorial, faktor pertama adalah suhu simpan terdiri dari 4 tingkat yaitu ruang $\left(28 \pm 1^{0}\right.$ C, $\mathrm{RH} 80 \%)$, inkubator $\left(20^{\circ} \mathrm{C}, \mathrm{RH} 90 \%\right)$, inkubator $\left(5^{\circ} \mathrm{C}, \mathrm{RH} 95 \%\right)$ dan deep freezer $\left(-20^{\circ} \mathrm{C}, \mathrm{RH} 65 \%\right)$. Faktor kedua adalah lama penyimpanan tediri dari 6 tingkat yaitu $0,1,2$, 3,4 dan 5 bulan. Masing-masing perlakuan dengan 3 ulangan.

Biji dibersihkan dari kulit buahnya, dicuci dan dikering-anginkan. Selanjutnya, dikemas dalam kantong aluminium foil jumlahnya sesuai dengan perlakuan, masing-masing kantong diletakkan dalam berbagai suhu simpan sesuai perlakuan. Setiap bulan diambil sejumlah contoh biji untuk dilakukan pengukuran terhadap kadar air, kebocoran ion, uji tetrazolium dan uji perkecambahan. Nilai perkecambahan ditetapkan pada akhir pengamatan.

Pengukuran kadar air dengan cara menimbang biji sebanyak 2 gram untuk setiap ulangan dan dipanaskan dalam oven suhu $105^{\circ} \mathrm{C}$ selama 3 jam (sampai berat tetap). Kadar air dihitung berdasarkan berat basah.

Kebocoran ion diukur dengan cara merendam biji dalam air bebas ion dengan perbandingan $50 \mathrm{cc} / 5$ gram biji selama 24 jam pada suhu $15^{\circ} \mathrm{C}$, air rendaman diukur dengan alat CONDUCTIVITY METER dengan satuan $\left(\left(\mu \mathrm{Scm}^{-1}\right)^{8)}\right.$. Uji tetrazolium menggunakan larutan tetrazolium 0,5\%. Biji dipisahkan dari kulit bijinya, diimbibisikan dengan aquadest, kemuduan ditetesi dengan larutan tetrazolium dan disimpan dalam inkubator suhu $35-40^{\circ} \mathrm{C}$. Biji yang masih baik akan berwana merah.

Uji viabilitas dengan cara mengecambahkan biji dalam bak perkecambahan dengan media pasir bersih, masing-masing 3 ulangan, setiap ulangan 
terdiri dari 20 biji. Sebelum ditanam biji dicuci dengan fungisida Dithane M45 . Untuk memecahkan dormansi dilakukan dengan GA3 100 ppm pada uji perkecambahan.

Nilai perkecambahan ditetapkan pada akhir pengamatan (10 Minggu Setelah Tanam) dengan rumus Gzabator ${ }^{9}$ sebagai berikut:

$$
\begin{aligned}
\mathrm{GV}= & \mathrm{PV} \times \mathrm{XDG} \\
\mathrm{GV}= & \text { Germination Value (Nilai } \\
& \text { perkecambahan) } \\
\mathrm{PV}= & \text { Peak Value (nilai puncak) } \\
\mathrm{MDG}= & \text { Mean Daily Germination (rata- } \\
& \text { rata perkecambahan harian) }
\end{aligned}
$$

\section{HASIL DAN PEMBAHASAN}

Hasil penelitian secara umum menunjukkan bahwa perlakukan GA3 dapat memecahkan dormansi biji $P$. Javanica sebelum maupun setelah penyimpanan pada berbagai suhu. Suhu penyimpanan berpengaruh nyata terhadap peubah kebocoran ion dan uji tetrazolium (Tabel 1), daya kecambah dan nilai perkecambahan biji (Tabel 2). Sedangkan lama penyimpanan berpengaruh terhadap semua peubah yang diamati (Tabel 1 dan 2 ). Suhu penyimpanan terbaik adalah suhu $5^{\circ} \mathrm{C}$, setelah 5 bulan penyimpanan perkecambahan tetap tinggi yaitu $73,33 \%$, sedangkan pada perlakuan lain perkecambahan $<50 \%$. Persentase perkecambahan menurun secara gradasi seiring dengan lamanya penyimpanan (Tabel 2)

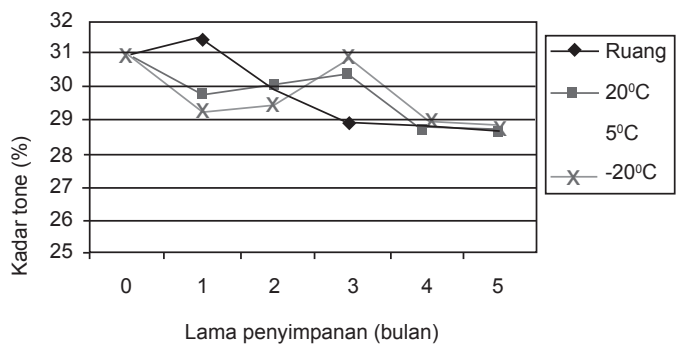

Gambar 1. Pengaruh suhu dan lama penyimpanan terhadap kadar air biji P. Javanica

\subsection{Kadar air}

Hasil pengukuran kadar air pada berbagai suhu simpan yaitu berkisar antara $29,40 \%-29,82 \%$ tidak menunjukkan perbedaan yang nyata secara statistik (Tabel 1). Sedangkan kadar air sejak awal sampai 5 bulan penyimpanan berkisar antara

\begin{tabular}{|c|c|c|c|c|}
\hline Perlakuan & & $\begin{array}{c}\text { Kadar air } \\
(\%)\end{array}$ & $\begin{array}{c}\text { Kebocoran } \\
\text { ion } \\
\left(\mu \mathrm{Scm}^{-1}\right)\end{array}$ & $\begin{array}{c}\text { Uji Tetrazo- } \\
\text { lium } \\
(\%)\end{array}$ \\
\hline \multirow{4}{*}{ Suhu simpan } & Ruang $\left(28 \pm 1^{\circ} \mathrm{C}, \mathrm{RH} 80 \%\right)$ & $29,78 \mathrm{a}$ & $166512 \mathrm{a}$ & $56,11 \mathrm{~b}$ \\
\hline & inkubator $\left(20^{\circ} \mathrm{C}, \mathrm{RH} 90 \%\right)$ & $29,82 a$ & $26239 \mathrm{~b}$ & $87,78 \mathrm{a}$ \\
\hline & inkubator ( $\left.5^{\circ} \mathrm{C}, \mathrm{RH} 85 \%\right)$ & $29,48 \mathrm{a}$ & $11626 \mathrm{c}$ & $87,22 \mathrm{a}$ \\
\hline & Deep freezer $\left(-20^{\circ} \mathrm{C}, \mathrm{RH} 90 \%\right)$ & $29,40 a$ & $17462 \mathrm{c}$ & $6,11 \mathrm{c}$ \\
\hline \multirow[t]{6}{*}{ Lama simpan (bulan) } & 0 & $30,30 \mathrm{a}$ & $9680 \mathrm{c}$ & $54,17 \mathrm{bc}$ \\
\hline & 1 & $29,96 a b$ & 5519 c & $71,67 \mathrm{a}$ \\
\hline & 2 & $29,84 a b$ & $7313 \mathrm{c}$ & $68,33 a b$ \\
\hline & 3 & $30,00 a b$ & $10865 \mathrm{c}$ & $53,33 \mathrm{c}$ \\
\hline & 4 & 29,12 bc & $113218 b$ & $54,17 \mathrm{bc}$ \\
\hline & 5 & $28,50 \mathrm{c}$ & $186163 a$ & $54,17 \mathrm{bc}$ \\
\hline
\end{tabular}
$28,50 \%-30,30 \%$, ada kecenderungan menurun dan berbeda nyata setelah 4 dan 5 bulan penyimpanan. Interaksi kadar

Tabel 1. Pengaruh suhu simpan dan lama penyimpanan terhadap kadar air, kebocoran ion dan uji tetrazolium biji $P$. Javanica

Keterangan: angka-angka yang diikuti dengan huruf yang sama pada lajur yang sama tidak berbeda nyata pada uji Duncan $5 \%$ 
air pada berbagai suhu simpan dan lama penyimpanan disajikan pada Gambar 1. Kelembaban udara $(\mathrm{RH})$ pada berbagai suhu simpan yang relatif tinggi yaitu berkisar antara $65 \%$ - 90\% tidak mempengaruhi kadar air biji secara nyata. ${ }^{3)}$ menyatakan bahwa terjadi hubungan antara kelembaban relatif dan kadar air selama penyimpanan, pada kelembaban makin tinggi maka kadar air semakin tinggi. Biji mempunyai sifat higroskopis yang sangat mudah untuk menyerap air dan udara di sekitarnya sampai batas keseimbangan.

\subsection{Kebocoran ion}

Suhu dan lama penyimpanan berpengaruh nyata terhadap kebocoran ion biji $P$. javanica. (Tabel 1). Interaksi antara suhu dan lama penyimpanan terhadap kebocoran ion disajikan pada Gambar 2. Perbedaan suhu simpan dengan berbagai suhu menghasilkan angka kebocoran ion yang bervariasi yaitu berkisar 11626-166512 $\mu \mathrm{Scm}^{-1}$. Angka kebocoran ion tertinggi nampak pada suhu ruang dan berbeda nyata dengan perlakuan lain (Tabel 1). Angka kebocoran ion mulai meningkat cukup drastis pada suhu ruang, penyimpanan 4 bulan (Gambar 2), hasil ini dapat dikaitkan dengan daya kecambah yang juga menurun sampai angka 0\% pada perlakuan tersebut (Gambar 4). Tingkat kerusakan biji dihubungkan dengan konsentrasi kebocoran ion yang dapat diukur pada larutan perendam biji. Kebocoran ion merupakan refleksi dari terjadinya degradasi membran sel. Biji yang mengalami kebocoran ion mengakibatkan terjadinya kemunduran proses - proses biokimia dalam biji. Semakin tinggi konsentrasi kebocoran ion memberikan indikasi terjadinya kerusakan biji yang semakin tinggi ${ }^{3}$ )

\subsection{Uji Tetrazolium}

Uji statistik menunjukkan bahwa masing-masing faktor yaitu suhu dan lama penyimpanan berpengaruh nyata terhadap

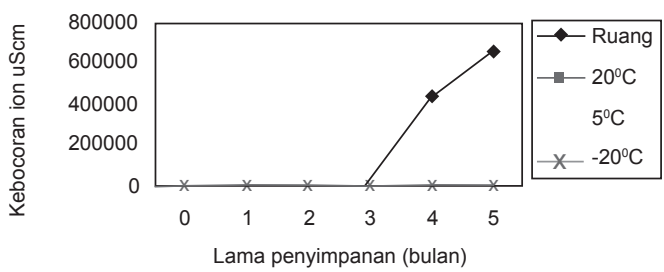

Gambar 2. Pengaruh suhu dan lama penyimpanan terhadap Ion biji $P$. Javanica

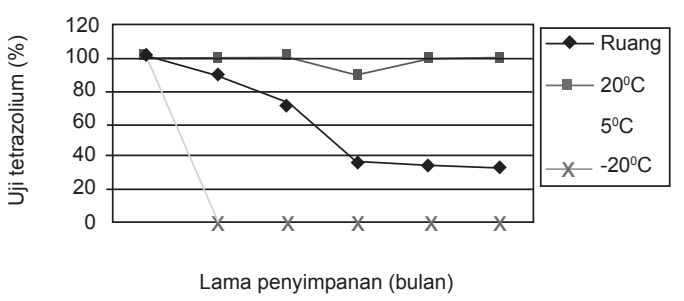

Gambar 3. Pangaruh suhu dan lama penimpanan uji tetrazolium biji $P$. Javanica

hasil uji tetrazolium. Kapasitas fisiologis awal yang diindikasikan oleh adanya kegiatan enzym/katalisator hidrolisis yang bereaksi dengan indikator warna merah pada uji tetrazolium menghasilkan angka yang sangat bervariasi (Tabel 1) yaitu antara 6,11\% $87,78 \%$ (suhu simpan) dan 53,33\% - 71,67\% (lama simpan). Penyimpanan suhu rendah $\left(5^{\circ} \mathrm{C}\right.$ dan $20^{\circ} \mathrm{C}$ ) menghasilkan uji tetrazolium yang lebih tinggi dibandingkan suhu ruang dan deep freezer. Persentase warna merah tertinggi diperoleh pada penyimpanan inkubator suhu $5^{\circ} \mathrm{C}$ yaitu $87,78 \%$ diikuti inkubator suhu $20^{\circ} \mathrm{C}$ yaitu $87,22 \%$, ke dua perlakuan tersebut berbeda nyata dengan penyimpanan suhu ruang $\left(28 \pm 1^{\circ} \mathrm{C}\right)$ dan deep freezer $\left(-20^{\circ} \mathrm{C}\right)$ (Tabel 1). Pada Gambar 3 dapat dilihat bahwa uji tetrazolium di atas $80 \%$ diperoleh pada perlakuan suhu simpan $5^{\circ} \mathrm{C}$ dan $20^{\circ} \mathrm{C}$ sejak awal sampai 5 bulan penyimpanan. Penyimpanan dalam deep frezeer suhu $-20^{\circ} \mathrm{C}$ sejak 1 bulan penyimpanan menghasilkan uji tetrazolium $0 \%$, yang mendikasikan embrio telah mengalami kerusakan. Biji dengan kadar air awal yang relatif tinggi (>30\%) jika disimpan pada suhu dibawah $0^{\circ} \mathrm{C}$ akan terbentuk kristal es dan menyebabkan kematian biji11) 


\subsection{Daya kecambah}

Penyimpanan biji pada berbagai suhu simpan dan lama penyimpanan masingmasing mempengaruhi daya kecambah secara nyata, baik dengan maupun tanpa GA3. (Tabel 3). Perlakuan GA3 berhasil memecahkan dormansi biji $P$. javanica sebelum maupun setelah penyimpanan. Suhu penyimpanan $5^{\circ} \mathrm{C}$ menghasilkan daya kecambah tertinggi yaitu $83,33 \%$ dengan GA3 dan 42,5\% tanpa GA3 (Tabel 3). Daya kecambah mengalami penurunan secara gradasi seiring dengan lamanya penyimpanan. Pengamatan sejak 0 sampai penyimpanan 5 bulan menunjukkan bahwa pada berbagai suhu simpan yaitu ruang suhu $28 \pm 1^{\circ} \mathrm{C}$ dan inkubator suhu $5^{\circ} \mathrm{C}$ dan $20^{\circ} \mathrm{C}$ daya kecambah biji dengan perlakuan GA3 lebih tinggi dibandingkan tanpa GA3 kecuali pada deep freezer suhu $-20^{\circ} \mathrm{C}$ (Gambar 3 a). Pada suhu simpan di deep freezer $\left(-20^{\circ}\right.$ C, RH..) biji tidak berkecambah sejak 1 bulan penyimpanan. Sebelum disimpan, daya kecambah biji tanpa GA3 adalah 18,33\% dan dengan GA3 mencapai 91,67\%. Daya kecambah menurun drastis( $<50 \%)$ setelah 3 bulan penyimpanan.(Tabel 2 ).

Dari fenomena tersebut ada indikasi bahwa biji $P$. javanica mempunyai sifat intermediet (antara ortodok dan rekalsitrant) yaitu dengan kadar air biji relatif tinggi $(<20 \%)$, daya berkecambah dapat dipertahankan tetap tinggi pada suhu simpan yang lebih rendah $\left(5^{\circ} \mathrm{C}\right.$ dan $20^{\circ} \mathrm{C}$ ) dibandingkan pada suhu tinggi $\left(28 \pm 1^{\circ} \mathrm{C}\right)$ (Tabel 1 dan 2), namun pada suhu simpan - $20^{\circ}$ C biji tidak berkecambah sejak 1 bulan penyimpanan. Dilaporkan bahwa jenis biji-biji intermediet yang berasal dari daerah tropik akan mati dengan cepat pada suhu lebih rendah $10^{\circ} \mathrm{C}$ dan beberapa kasus dibawah suhu $0^{\circ} \mathrm{C}{ }^{4,5,6,7)}$. Dari data yang diperoleh menunjukkan bahwa perlakuan GA3 100 ppm dapat memecahkan dormansi biji setelah penyimpan 5 bulan pada berbagai suhu simpan. Pada penelitian sebelumnya dilaporkan bahwa penggunaan Iarutan
GA3 100 - 400 ppm mampu mempercepat dan meningkatkan daya kecambah biji $P$. javanica secara nyata yaitu $93-95 \%$ dalam waktu 2 minggu, sedangkan pada kontrol $<10 \%{ }^{16)}$. Juga pada biji Brucea javanica (Simaroebaceae) dilaporkan bahwa perlakuan GA3 500-1500 ppm dapat mempercepat dan meningkatkan perkecambahan. ${ }^{13)}$.Perendaman GA3 dapat menghilangkan lapisan yang membungkus biji yang menghalangi penetrasi air ke dalam embrio ${ }^{3)}$. Hungary dalam ${ }^{14)}$ melaporkan bahwa pemberian GA3 sangat meningkatkan aktivitas enzim $\alpha$ amylase dan protease yang diperlukan untuk perkecambahan. Dari semua perlakuan yang dicoba suhu simpan dalam inkubator suhu $5^{\circ} \mathrm{C}$ adalah yang terbaik, biji masih mampu berkecambah sampai $73,3 \%$ dengan perlakuan GA3 pada penyimpanan 5 bulan, sedangkan pada perlakuan lain perkecambahan $<50 \%$ (Tabel1).

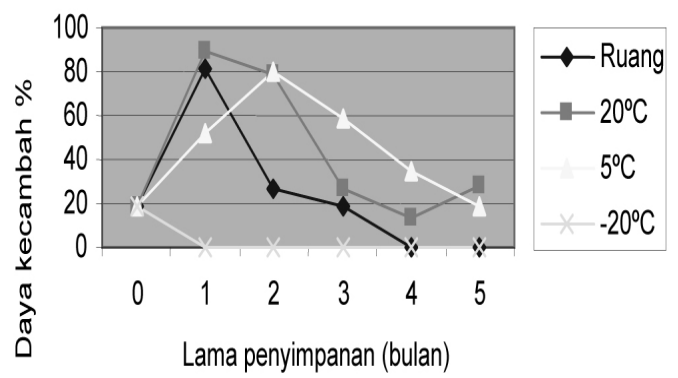

Gambar 3a. Pengaruh suhu dan lama penimpanan terhadap daya kecambahan biji P. Javanica

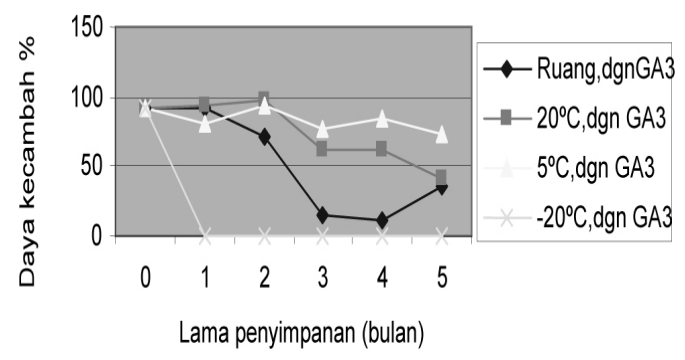

Gambar 3b. Pengaruh GA3 terhadap daya kecambah biji P. Javanica setelah penyimpanan pada berbagai suhu 


\subsection{Nilai perkecambahan}

Masing-masing faktor yaitu suhu dan lama penyimpanan berpengaruh nyata terhadap nilai perkecambahan. Perlakuan GA3 100 ppm menghasilkan nilai perkecambahan yang lebih tinggi dibandingkan tanpa GA3 pada berbagai perlakuan suhu dan lama penyimpanan (Tabel 3 ). Penyimpanan dalam inkubator $\left(20^{\circ} \mathrm{C}\right)$ menghasilkan nilai perkecambahan tertinggi dan berbeda nyata secara statistik dibandingkan perlakuan suhu lain, baik dengan maupun tanpa GA3. Nilai perkecambahan merupakan kombinasi antara persentase perkecambahan dan kecepatan perkecambahan ${ }^{9}$. Nilai perkecambahan pada berbagai suhu suhu simpan berkisar 0,036,48 tanpa GA3 dan 0,85 - 14, 41 dengan GA3. Nilai perkecambahan yang tinggi mengindikasikan bahwa biji mempunyai laju perkecambahan yang cepat dan persentase perkecambahan yang tinggi. Pada Tabel 3 dapat dilihat bahwa nilai perkecambahan tertinggi $(14,41)$ diperoleh pada penyimpanan di inkubator suhu $20^{\circ} \mathrm{C}$, namun persentase perkecambahan tertinggi (83,33\%). diperoleh pada perlakuan inkubator suhu $5^{\circ} \mathrm{C}$. Hal ini dapat dipahami karena meskipun pada suhu $20^{\circ} \mathrm{C}$ persentase perkecambahan lebih rendah $(74,44 \%)$ namun biji lebih serentak/ cepat berkecambah sehingga diperoleh nilai perkecambahan yang lebih tinggi. Sebaliknya pada suhu simpan $5^{\circ} \mathrm{C}$ menghasilkan persentase perkecambahan lebih tinggi namun perkecambahan biji lebih lambat/ kurang serentak sehingga menghasilkan nilai perkecambahan lebih kecil.

\section{KESIMPULAN dan SARAN}

Dari penelitian ini dapat disimpulkan bahwa GA3 100 ppm mampu memecahkan dormansi biji $P$. javanica sebelum maupun setelah penyimpanan pada berbagai suhu simpan kecuali suhu $-20^{\circ} \mathrm{C}$. Penyimpanan biji $P$. javanica pada inkubator suhu rendah yaitu $20^{\circ} \mathrm{C}$ dan $5^{\circ} \mathrm{C}$ lebh baik dibandingkan suhu ruang $\left(28 \pm 1^{\circ} \mathrm{C}, \mathrm{RH} 80 \%\right)$ dan deep freezer (- $\left.20^{\circ} \mathrm{C}, \mathrm{RH} 90 \%\right)$. Suhu simpan yang terbaik adalah inkubator suhu $5^{\circ} \mathrm{C}, \mathrm{RH}$ yaitu mampu mempertahankan viabilitasnya $>50 \%$ sampai 5 bulan penyimpanan dan menghasilkan perkecambahan tertinggi yaitu $73,33 \%$ dengan GA3 dan 18,33\% tanpa GA3, sedangkan pada perlakuan lain menghasilkan viabilitas < $50 \%$. Nilai perkecambahan tertinggi yaitu 14,1 diperoleh pada perlakuan suhu simpan $20^{\circ} \mathrm{C}$. Tidak disarankan menyimpan biji $P$ javanica pada deep freezer $\left(-20^{\circ} \mathrm{C}, \mathrm{RH} 90 \%\right)$

Tabel 2. Pengaruh suhu simpan dan lama penyimpanan terhadap daya kecambah dan nilai perkecambahan biji $P$. Javanica

\begin{tabular}{|c|c|c|c|c|c|}
\hline \multirow{2}{*}{ Perlakuan } & & \multicolumn{2}{|c|}{ Daya kecambah (\%) } & \multicolumn{2}{|c|}{ Nilai perkecambahan } \\
\hline & & Tanpa GA3 & Dengan GA3 & Tanpa GA3 & Dengan GA3 \\
\hline \multirow{4}{*}{$\begin{array}{l}\text { Suhu } \\
\text { simpan }\end{array}$} & Ruang $\left(28 \pm 1^{\circ} \mathrm{C}, \mathrm{RH} 80 \%\right)$ & $24,17 \mathrm{~b}$ & $52,78 \mathrm{c}$ & $2,20 \mathrm{c}$ & $7,26 \mathrm{~b}$ \\
\hline & inkubator $\left(20^{\circ} \mathrm{C}, \mathrm{RH} 90 \%\right)$ & $43,61 \mathrm{a}$ & $74,44 \mathrm{~b}$ & $6,48 \mathrm{a}$ & $14,41 \mathrm{a}$ \\
\hline & inkubator ( $\left.5^{\circ} \mathrm{C}, \mathrm{RH} 85 \%\right)$ & $42,50 \mathrm{a}$ & $83,33 \mathrm{a}$ & $4,41 \mathrm{~b}$ & $9,53 \mathrm{~b}$ \\
\hline & Deep freezer $\left(-20^{\circ} \mathrm{C}, \mathrm{RH} 90 \%\right)$ & $3,06 \mathrm{c}$ & $15,28 d$ & $0,03 d$ & $0,85 \mathrm{c}$ \\
\hline \multirow{6}{*}{$\begin{array}{l}\text { Lama } \\
\text { simpan } \\
\text { (bulan) }\end{array}$} & 0 & $18,33 \mathrm{~d}$ & $91,67 \mathrm{a}$ & $0,17 \mathrm{c}$ & $4,54 \mathrm{c}$ \\
\hline & 1 & $56,83 \mathrm{a}$ & $66,25 \mathrm{~b}$ & $9,52 \mathrm{a}$ & $16,52 \mathrm{a}$ \\
\hline & 2 & $46,25 \mathrm{~b}$ & $65,42 \mathrm{~b}$ & $7,69 \mathrm{~b}$ & $16,53 \mathrm{a}$ \\
\hline & 3 & $25,83 \mathrm{c}$ & $38,33 \mathrm{c}$ & $1,43 \mathrm{c}$ & $1,92 \mathrm{~cd}$ \\
\hline & 4 & $12,08 \mathrm{~d}$ & $39,58 \mathrm{c}$ & $0,86 \mathrm{c}$ & $7,63 \mathrm{~b}$ \\
\hline & 5 & $11,67 d$ & $37,50 \mathrm{c}$ & $0,00 \mathrm{c}$ & $0,93 d$ \\
\hline
\end{tabular}

Keterangan: Angka-angka yang diikuti dengan huruf yang sama pada lajur yang sama tidak berbeda nyata pada uji Duncan $5 \%$ 


\section{UCAPAN TERIMA KASIH}

Penulis mengucapkan terima kasih kepada Bpk. Prof. Dr. Hadi Sutarno APU yang telah berkenan memeriksa dan memberi masukan pada tulisan ini, sdr. Ir. Sri Rahayu sebagai tenaga honorer dan Sdr. Aah teknisi Laboratorium Makropropagasi yang telah membantu dalam pelaksanaan penelitian ini.

\section{DAFTAR PUSTAKA}

1. Bahktiar, A. 2005. Aneka Tumbuhan Obat di Indonesia Bisa Punah. URL: http://www.gatra.com/versi_cetak. php?id=86275 (04/27/2006)

2. Bahktiar A. 2007. Rendah pemanfaatan hasil hutan non kayu di Indonesia http://www.antara.co.id/arc/2007/4/23 (18/05/2008)

3. Copeland, 1976. Principles of Seed Science and Technology. Burgess Publishing

Company. Minneapolis, Minnesota

4. Ellies, R.H., T.D. Hong , E.H. Roberts. 1990a. An intermediate category of seed

storage behaviour. I. Coffee. Journal of Experimental Botany 41: 1167 -1174

5. Ellies, R.H, T.D. Hong and E.H. Roberts. 1991 a. An intermediate category of seed storagr behaviour? II. Effects of proveance, immaturity, and imbibition on desiccation-tolerance in coffee. Journal of Experimental Botany 41: $1167-1174$

6. Ellies R.H, T.D. Hong and E.H. Roberts 1991 b. Effects of storage temperature and

moisture on the germination of papaya seeds. Seed Science Research 1: 69 $-74$

7. Ellies R.H, E.H. Roberts and U.Sutisna. 1991 c. Seed storage behaviour in Elaeis guineensis. Seed Science Research 1: $99-104$

8. Hanson,J. 1983. Peranan biji dalam pelestarian tumbuhan. Final Technical Report.

Seed Storage Project Bogor.

Indonesia: 139-145

9. Hartman. H.T., D.E. Kester, F.T. Davies, R.L.Geneve. 1997. Plant Propagation.

Principles and Practices. Prentice Hall. Upper Saddle, New Jersey

10. Hidayat, S. 2003. Picrasma javanica Blume. In: Medicinal and Poisonous Plant 3,

PROSEA, Plant Resources of SouthEast Asia No. 12(3). Lemmens, R.H.M.J. and N. Bunyapraphatsara (Eds.). Backhuys Publishes, Leiden. p. 329-330.

11. Leopold A.C. and C.W. Vertucci, 1989. Moisture as a regulator of physiological reaction in seeds. In Seed Moisture Content. CSSA Special Publication Number

12. Praptiwi; Harapini, M,; \& Chairul. 2007. Uji Aktivitas Antimalaria secara In-Vivo Ekstrak Ki Pahit (Picrasma javanica) pada Mencit yang Diinfeksi Plasmodium berghei. Jurnal of Biological Diversity. Biodiversitas (8)2: 113-114

13. Setyowati, N. dan N.W. Utami, 2007. Pengaruh Tingkat Ketuaan Buah, Perlakuan Perendaman air dan GA3 Terhadap Perkecambahan Brucea javanica L. Merr. Biodiversitas Journal of Biological Diversity 9(1): 13 -16

14. Thomson, J,R, 1983, Advances in Research and Technology of Seeds, Part 8, Pudoc, Wageningen

15. Tsay, $H, 2002$, Use of tissure culture for mass propagation of pathogen free plants,

Http://www,fftc,agnet,org/library/article/ tb158,html (14/07/07)

16. Utami, N.W. 2007. Respon perkecambahan biji Picrasma javanica Terhadap Perlakuan Pematahan dormansi. Laporan Teknik 2008. Unpublish 